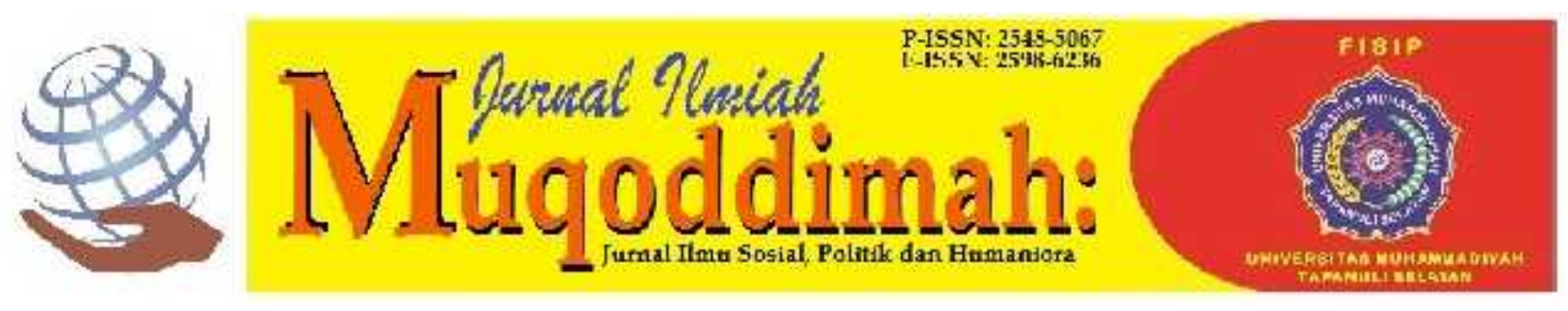

\title{
Transparansi Dalam Proses Pengangkatan Perangkat Nagari
}

\author{
Abdiana llosa $^{1)}$, Saipul Al Sukri²), Rudiadi ${ }^{3)}$ \\ Fakultas Ekonomi dan IImu Sosial Universitas Islam Negeri Sultan Syarif Kasim Riau 1), 2) \\ Fakultas Syariah dan Hukum Universitas Islam Negeri Sultan Syarif Kasim Riau ${ }^{3)}$ \\ JI. H. R. Soebrantas KM 15,5 ,Tuah Madani, Tampan, Pekanbaru, Riau, Indonesia \\ ella.abdian@yahoo.com \\ saipul.a.sukri@uin-suska.ac.id \\ rudiadi.r@uin-suska.ac.id
}

\begin{abstract}
Abstrak
Perangkat desa memiliki kewajiban dan tanggungjawab besar untuk membantu Kepala Desa/Nagari melaksanakan tugas, kewajiban serta memberikan pelayanan terbaik kepada masyarakat. Pemilihan perangkat desa/nagari yang tepat akan menunjanag pelaksanaan tugas dan kewajiban tersebut. Mengingat kedudukan perangkat desa yang begitu penting, diperlukan proses rekruitmen, prsedur serta persyaratan yang tepat bagi calon perangkat desa tersebut. Tujuan akhir yang ingin diperoleh dari penelitian ini adalah untuk mengetahui bagaimana implementasi serta hambatan asas transparansi dalam proses pengangkatan perangkat Nagari sontang cubadak Kabupaten Pasaman Sumatera Barat. Teknik yang digunakan dalam Pengumpulan data penelitian ini menggunakan teknik wawancara (key informan). adapun jenis serta sumber data yang digunakan pada penelitian ini adalah jenis data primer dan data sekunder. Selanjutnya data tersebut dianalisis dengan teknik deskriptif kualitatif. Hasil yang diperoleh pada penelitian ini menunjukkan adanya tahapan yang tidak transparan dalam pengangkatan perangkat Nagari sontang cubadak. Ini terjadi karena kurangnya transfaransi dalam penjaringan, perekrutan calon perangkat. Hal ini dibuktikan dari banyaknya masyarakat Nagari sontang cubadak yang tidak mengetahui proses dan hanya mengetahui hasil dari pengangkatan tersebut. Selain itu pengawasan dari pihak kecamatan dan kurang baiknya komunikasi antara pihak pemerintahan Nagari dan masyarakat juga menjadi penyebab gagalnya pengangkatan perangkat pemerintahan Nagari Sontang Cubadak.
\end{abstract}

Keyword: Otonomi Daerah, Asas Transparansi, Perangkat Nagari

\begin{abstract}
Village officials have a great obligation and responsibility to help the Village Head carry out his duties, obligations and provide the best service to the community. The selection of the right village officials will support the implementation of these tasks and obligations. Considering the position of the village apparatus that is so important, the recruitment process, procedures and requirements that are appropriate for the candidate village apparatus are needed.The purpose of this study was to determine the implementation and constraints of the principle of transparency in the appointment of the sontang cubadak Nagari village in Pasaman, West Sumatra. Data collection in this study used interview techniques (key informants). While the types and sources of data used in this study are primary and secondary data. From there the data is then analyzed in a qualitative descriptive way. The results of this study provide evidence that transparency does not occur in the process of appointing
\end{abstract}


Sontang Cubadak Nagari. This happens because of the lack of transparency in the selection, recruitment of candidates for the device. This is evidenced from the many people of Sontang Cubadak village who do not know the process and only know the results of the appointment. In addition, the supervision of the sub-district and the lack of good communication between the Nagari government and the community also caused the failure of the appointment of the Sontang Cubadak village government apparatus.

Keyword: Regional Autonomy, Transparency Principle, Nagari's Officer

\section{PENDAHULUAN}

Indonesia merupakan salah satu negara kepulauan yang wilayah teritorialnya terbentang dari sabang sampai merauke, merupakan gugusan kepulauan terluas di dunia. Wilayah Indonesia kemudian dibagi atas daerah-daerah otonom sebagai upaya dalam percepatan pembangunan nasional. Dalam realitasnya Desa merupakan pemilik otonomi sebenarnya yang selama berabad-abad lalu menjadi unsur penggerak masyarakat indonesia. Tidak hanya itu, Desa sebagai sebagai komunitas adat maupun sebagai unit pemerintahan terendah telah membuktikan dirinya memiliki peran penting, baik di masa perjuangan maupun sesudah kemerdekaan (Somad, 2012). Menurut Siagian 1989 (dalam Suharto, 2016) desa terjemahkan sebagai suatu daerah yang berada diluar perkotaan atau diluar pusat kegiatan pemerintah. Lahirnya UndangUndang Nomor 23 Tahun 2014 Tentang Pemerintahan Daerah adalah perwujudan dari konsep desentralisasi, yang artinya melimpahkan hak kepada daerah untuk mengurus urusan pemerintahan di daerahnya.

Dalam Pasal 2 ayat (2) dijelaskan bahwa:

"Daerah kabupaten/kota dibagi atas kecamatan dan kecamatan dibagi atas kelurahan dan/ Desa. Suatu Desa ataupun kelurahan merupakan unit terkecil terhadap perwujudan hak otonomi di Indonesia yang bersentuhan langsung dengan masyarakat."

Selain itu dalam Undang Nomor 23 Tahun 2014 juga dijelaskan bahwa dalam mengatur rumah tangga dapat disesuikan dengan karakter masing-masing daerah setempat. Hal ini terdapat dalam pasal 1 ayat 43 yang berbunyi:

"Desa adalah Desa dan Desa adat atau yang disebut dengan nama lain, selanjutnya disebut Desa, adalah kesatuan masyarakat hukum yang memiliki batas wilayah yang berwenang untuk mengatur dan mengurus urusan pemerintahan, kepentingan masyarakat setempat berdasarkan prakarsa masyarakat, hak asal usul, dan/atau hak tradisional yang diakui dan dihormati dalam sistem pemerintahan Negara Kesatuan Republik Indonesia".

Pelimpahan wewenang yang seluas-luasnya kepada pemerintah dilakukan demi tercapainya cita-cita dan tujuan pembangunan nasional melalui partisipasi dari masyarakat dalam proses penyelenggaraan pemerintahan. Secara sadar atau tidak, Indonesia memiliki begitu banyak keragaman yang kemudian menjadi sumber kekayaan kultural bagi Indonesia (Kushandajani, 2016). Menurut (Romli, \& Nurlia, 2017) Pemerintahan desa merupakan unit terdepan (ujung tombak) dalam pelayanan kepada masyarakat serta menempati peran tombak strategis untuk keberhasilan semua program. Artinya, proses pembangunan di wilayah Desa harus menjadi prioritas utama dalam cita-cita pembangunan nasional. 
Sejalan dengan permasalahan ini, Meigelheis (2018) menyampaikan bahwa Salah satu yang menjadi tolok ukur keberhasilan suatu pemerintahan dalam pembangunan negara dapat dilihat dari keberhasilan pembangunan Desa. Utami (2015) dan Badriyah (2017) juga mengungkapkan dalam penelitiannya tentang adanya pengaruh dalam proses perekrutan perangkat pemerintahan Desa terhadap kualitas atau kinerja yang dilakukan suatu pemerintahan Desa. Faturrahman (2018) dalam penelitiannya menyebutkan proses perekrutan perangkat desa secara terbuka dan melibatkan pengawasan masyarakat secara langsung dapat mengurangi rasa curiga antar masyarakat.

Untuk memberikan pelayanan dan percepatan pembangunan suatu daerah yang lebih kecil strukturnya seperti Desa atau dengan sebutan lain, maka pemerintah menerbitkan Undang-undang Nomor 6 Tahun 2014 Tentang Desa. Adanya momentum yang berkaitan pelimpahan wewenang kepada pemerintah Desa ini, tentu menjadi peluang bagi Desa untuk memastikan pembangunan infrastruktur serta tumbuh dan berkembangnya hukum adat serta kebiasaan-kebiasaan yang selama ini ada dalam kehidupan masyarakat di Desa. Oleh sebab itu, tradisi serta kebiasaan yang ada di Desa seperti yang terdapat di Sumatera Barat dengan Sistem Pemerintahan Nagari tentu juga bisa terjaga kemurniannya dengan adanya undang-undang ini.

Nagari berdasarkan PERDA Kabupaten Pasaman No 11 Tahun 2016 padal 1 angka (1) berbunyi:

"Nagari merupakan suatu kesatuan masyarakat hukum yang memilki batas wilayah dan berhak untuk mengatur serta mengurus segala urusan yang ada di wilayah pemerintahannya, serta kepentingan masyarakat setempat berdasarkan prakarsa dari masyarakat, hak asal usul, dan/atau hak tradisonal yang diakui serta dihormati dalam Sistem Pemerintah Negara Kesataun Republik Indonesia".

Keberhasilan penyelenggaraan pemerintahan Nagari dapat berjalan dengan lancar umumnya dipengaruhi oleh beberapa factor pendukung. Salah satunya wali Nagari harus mempunyai hubungan komunikasi yang baik atau hubungan kerja yang baik dengan perangkat Desa lainnya, karena untuk tercapainya suatu sistem pemerintahan yang baik sangat diperlukannya sinergitas ataupun kekompakan antara seorang atasan dan bawahan begitu juga sebaliknya, jadi sangat diperlukan juga perangkat Nagari yang mempunyai kinerja yang baik.

Permendagri Nomor 83 Tahun 2015 sudah mengatur tentang tatacara pengangkatan serta pemberhentian perangkat Desa. Dalam pasal 2 dijelaskan bahwa:

"perangkat pemerintahan Desa/ Nagari diangkat oleh Kepala Desa/Nagari dari warga Desa/ Nagari yang secara aturan hokum telah memanuhi kriteria yang diharapkan, hal ini juga telah diatur didalam Peraturan daerah Kabupaten Pasaman Nomor 11 Tahun 2016 Tentang Tatacara dan Proses pengangkatan serta pemberhentian perangkat Nagari."

Pada bulan agustus 2017 Kabupaten Pasaman melaksanakan pemilihan perangkat Nagari di masing-masing Nagari dan telah menyebarluaskan informasi ataupun pengumuman hasil dari setiap seleksi yang telah diadakan, akan tetapi didapati beberapa Nagari yang gagal dilantik oleh Bupati. Hal ini diketahuidari surat edaran yang diterbitkan oleh Bupati Kabupaten Pasaman dengan Nomor Surat 140/4197/PemNag-2017 tentang Pengangkatan dan Pemberhentian Perangkat Nagari. 
Tabel 1

Nama-nama Nagari di Kecamatan Padang Gelugur

\begin{tabular}{cll}
\hline No & \multicolumn{1}{c}{ Nagari } & \multicolumn{1}{c}{ Keterangan } \\
\hline 1 & Nagari Padang Gelugur & Tidak Dilantik \\
2 & Nagari Bahagia Padang Gelugur & Dilantik \\
3 & Nagari Sitombol Padang Gelugur & Dilantik \\
4 & Nagari Sontang Cubadak & Tidak Dilantik \\
\hline
\end{tabular}

Sumber : Kantor Camat Padang Gelugur

Seperti diketahui, Peragkat Desa/Nagari sebagaimana dijelaskan didalam pasal 48 Undang-undang tentang Desa yang berbunyi:

"perangkat Desa memiliki kewajiban dan tanggungjawab untuk membantu Kepala

Desa/Nagari dalam melaksanakan kebijakan terkait tugas serta memberikan pelayanan terbaik kepada masyarakat".

Mengingat kedudukan perangkat Desa yang penting, merupakan ujung tombak bagi pelayanan masyarakat, diperlukan pula proses rekruitmen yang tepat, mulai dari prsedur serta persyaratan bagi calon perangkat Desa, mekanisme serta tatacara pengangkatan, masa kerja, kedudukan keuangan, penjelasan terkait tugas, tindakan yang dilarang serta mekanisme dan tatacara pemberhentian. Selain itu Proses rekruitmen Perangkat Desa diharapkan lebih transparan dan akuntabel sesuai dengan cita-cita good goverment. Menurut Dwiyanto (2006) Setidaknya ada 9 prinsip yang harus di terapkan dalam mewuhudkan good govermance antara lain: 1) Partisipasi dari masyarakat; 2) Penegakan terhadap supremasi hukum; 3) Transparansi; 4) Peduli pada stake holder; 5) Berorientasi pada konsensus; 6) Kesetaraan; 7) Efektifitas dan efisiensi; 8) Akuntabilitas; 9) Visi strate.

Transparansi merupakan salah satu prinsip good governance. Menurut Andrianto (2007) Transapransi merupakan keterbukaan secara transparan, menyeluruh, dan memberi ruang bagi partisipasi untuk masyarakat dalam proses pengelolaan sumber daya publik. Dari pengertian diatas dapat ditarik kesimpulan bahwa transparansi bukan hanya sekedar menyediakan informasi tentang penyelenggaraan pemerintahan, namun juga harus disertai dengan kemudahan bagi masyarakat untuk memperoleh informasi tersebut.

Salah satu tujuan transparansi adalah mewujudkan adanya rasa saling percaya antara pemerintah dengan publik. Pemerintah harus memberi informasi akurat, terutama yang berkaitan dengan masalah hukum, peraturan, dan hasil yang dicapai dalam proses pemerintahan, adanya mekanisme yang memungkinkan masyarakat mengakses informasi yang relevan, adanya peraturan yang mengatur kewajiban pemerintah daerah menyediakan informasi kepada masyarakat, serta menumbuhkan budaya di tengah masyarakat untuk mengkritisi kebijakan yang dihasilkan pemerintah daerah (Sedarmayanti, 2009). 
Tabel 2.

Konsep Operasiona

\begin{tabular}{|c|c|c|}
\hline Variabel & Indikator & Sub indikator \\
\hline \multirow[t]{3}{*}{ Pelaksanaan Azaz Transparansi } & Proses & $\begin{array}{l}\text { 1. Rekrutmen terbuka } \\
\text { 2. Proses seleksi } \\
\text { 3. Hasil seleksi }\end{array}$ \\
\hline & $\begin{array}{l}\text { Akses } \\
\text { informasi }\end{array}$ & $\begin{array}{l}\text { 1. Pengumuman } \\
\text { 2. Surat edaran } \\
\text { 3. Sosialisasi }\end{array}$ \\
\hline & Pengawasan & $\begin{array}{l}\text { 1. Pengawasan pemerintah } \\
\text { 2. Pengawasan masyarakat }\end{array}$ \\
\hline
\end{tabular}

Sumber: Peraturan daerah Nomor 11 Tahun 2016 Tentang prosedur Pengangkatan serta tata cara Pemberhentian Perangkat Nagari.

Berdasarkan uraian dan fenoma yang terjadi diatas, maka Peneliti tertarik untuk melakukan penelitian dengan judul "Azaz Transparansi Dalam Proses Pengangkatan Perangkat Nagari Kabupaten Pasaman Provinsi Sumatera Barat".

\section{METODE}

Model penelitian yang penulis gunakan dalam penelitian ini adalah model atau jenis penelitian deskriptif kualitatif. Penelitian deskritif kualitatif adalah suatu rangkaian pemecahan masalah yang diselidiki dengan menggambarkan objek penelitian secara mendetail dan kompherensif. Selain itu, teknik ini juga bertujuan untuk menarik generalisasi yang menjelaskan variabel yang menyebabkan suatu gejala atau kenyataan sosial. Penelitian deskriptif kualitatif bertujuan untuk memperoleh informasiinformasi keadaan saat ini dan kaitannya dengan variabel yang menyebabkan suatu gejala atau kenyataan sosial. Selanjutnya, Sumber data yang digunakan oleh Peneliti yaitu data primer serta dengan data sekunder.

Dalam penentuan informan Peneliti mengugunakan 2 cara yaitu dengan purposive sampling dan sampling purposiv, adalah teknik atau metode penelitian yang digunakan dengan cara sengaja atau merujuk pada orang yang dianggap dapat mewakili karakteristik atau informasi penting tentang objek yang akan diteliti. Teknik pengambilan sample yaitu snowball sampling dengan memakai key informan yaitu metode penentuan sampel yang diawali dari jumlah informan yang kecil, kemudian akan menuju pada jumlah informan yang lebih besar atau banyak (Sugiono, 2011)

Key informan adalah informasi kunci dari seseorang atau pihak yang mempunyai kuasa serta fungsi utama dalam menjalankan roda organisasi dan orang-orang memahami sepenuhnya seluk-beluk persoalan seluruh proses yang dijalnakan oleh organisasi dalam mencapai tujuannya.

Adapun sumber data atau informan diambil dari unsur pemerintah Nagari, calon perangkat Nagari, dan masyarakat setempat sebanyak 8 orang yaitu sebagai berikut:

1. Tim panitia seleksi 2 orang.

2. Camat Padang Gelugur 1 Orang

3. Pengawas tim panitia seleksi 1 Orang

4. Wali Nagari Sontang Cubadak 1 Orang

5. Masyarakat setempat 10 Orang 
Teknik pengumpulan data adalah cara pengumpulan data baik dari sumber objek penelitian. Metode yang digunakan sebagai berikut : Observasi, dokumentasi dan wawancara. Dalam pelitian ini peneliti menganalisis menggunakan metode deskriptif kualitatif.

\section{HASIL DAN PEMBAHASAN}

\section{Analisis Pelaksanaan Asas Transparansi.}

Berikut ini di paparkan tanggapan informan berkaitan dengan Pelaksanaan Asas Transparansi Dalam Proses Pengangkatan Perangkat Nagari Sontang Cubadak Kecamatan Padang Gelugur berdasarkan wawancara yang telah dilakukan.

\section{Pengawasan Terbuka}

Pengertian Pengawasan terbuka adalah dimana menciptakan rasa saling percaya antara pemerintah dan publik dimana pemerintah harus bisa memberi informasi yang akurat, terutama informasi -informasi yang berkaitan dengan masalah hukum, peraturan, serta hasil yang dicapai dalam penyelenggaraan pemerintahan.

a. Rekrutmen

Pengertian Rekrutmen dalam pengangkatan perangkat Nagari adalah dengan mempertimbangkan perekrutan secara terbuka dan sesuai proses yang telah di tetapkan sebagaimana juga diatur dalam Peraturan daerah Nomor 11 Tahun 2016 yang berisi Tentang tatacara pengangkatan serta prosedur pemberhentian perangkat Nagari.

Selanjutnya, Berdasarkan hasil atau kesimpulan dalam wawancara yang dilakukan kepada Bapak Hendra selaku Wali Nagari Sontang cubadak sebagai berikut:

"Proses rekrutmen perangkat Nagari sudah dilakukan sangat terbuka, dari dibentuknya panitia pengangkatan perangkat Nagari bersama dengan Camat Padang Gelugur, dan juga kami sudah memberikan informasi kepada seluruh masyarakat". (wawancara, 15 Maret 2018, jam 09.30 Wib, kantor Wali Nagari Sontang Cubadak)

Selanjutnya, penulis juga melakukan wawancara kepada pihak masyarakat Nagari Sontang Cubadak yaitu Bapak Makmur sebagai berikut:

"Kalau anak tanya proses rekrutmen ya menurut saya masih sangat kurang, karena banyak masyarakat yang tidak mengetahui akan diadakannnya pemilihan perangkat Nagari yang baru, tiba-tiba saja sudah dibuka pendaftarannya, dan waktu proses pendaftaran sempat terjadi tambahan waktu dari pihak kecamatan". (wawancara, 17 Maret 2018, 20.00 Wib, dirumah Bapak Makmur).

Selain itu, dari hasil wawancara yang diperoleh oleh Penulis ketikan berdiskusi dengan beberapa masyarakat dan obervasi penulis dapat simpulkan bahwa pengangakatan perangkat Nagari sontang ini masih kurang terbuka mengenai rekrutmen calon perangkat Nagari yang baru.

b. Proses seleksi

Pengertian Proses seleksi adalah serangkaian tahapan atau proses dalam kegiatan yang digunakan dalam menentukan apakah seseorang diterima atau tidak dalam suatu rangkaian perekrutan. Selanjutnya, Proses seleksi adalah 
seragkaian tindakan yang dilakukan pada pusat manajemen personalia. Analisa jabatan, perencanaan sumber daya manusia, dan penarikan dilakukan terutama untuk membantu seleksi personalia.

Berdasarkan wawancara yang dilakukan kepada Bapak Ahmad Sanusi selaku panitia tim seleksi pengangkatan perangkat Nagari sebagai berikut :

"Proses seleksi yang dilakukan sudah sangat benar, kami dari pihak panitia sudah membuat proses yang sangat bagus, pertama dilakukannya seleksi tertulis dan juga dilakukannya tes wawancara". (wawancara, 14 maret 2017, jam 11.10 wib).

Selanjutnya, penulis juga melakukan wawancara kepada pihak masyarakat Nagari Sontang cubadak yaitu bapak Makmur sebagai berikut:

"Untuk proses seleksi yang digunakan memang sudah benar, karena jadwal yang dilakukan panitia sesuai dengan peraturan yang sebelumnya dikeluarkan". (wawancara, 17 maret 2018, 20.00 Wib, dirumah bapak Makmur).

Berdasarkan hasil wawancara yang dilakukan oleh penulis secara langsung dengan beberapa masyarakat dan obervasi penulis dapat simpulkan bahwa proses seleksi yang lakukan oleh panitia tim seleksi perangkat Nagari sudah baik, dan juga telah sesuai dengan peraturan ataupun jadwal yang telah ditetapkan.

c. Hasil seleksi

Proses atau tahapan seleksi merupakan serangkaian kegiatan yang digunakan untuk memutuskan apakah pelamar diterima atau tidak. Langkahlangkah ini mencakup pemaduan kebutuhan-kebutuhan kerja pelamar dan organisasi.

Berdasarkan wawancara yang dilakukan kepada Bapak Hendra selaku Wali Nagari Sontang Cubadak sebagai berikut :

"Hasil seleksi mengenai pengangkatan perangkat Nagari ini sudah kami umumkan juga, dan kami juga sudah membuat surat edaran kepada semua kepala jorong mengenai hasil tersebut". (wawancara, 15 maret 2018, kantor Wali Nagari Sontang Cubadak).

Selanjutnya, penulis juga melakukan wawancara kepada pihak masyarakat Nagari Sontang cubadak yaitu bapak Indra sebagai berikut:

"Hasil seleksi perangkat Nagari ini sangat lama sekali untuk bisa di ketahui oleh masyarakat, setelah selesainya seleksi masyarakat belum juga mengetahui hasilnya." (wawancara, 18 maret 2018, 19.30 Wib, dirumah bapak Indra).

Berdasarkan kesimpulan yang diperoleh dari hasil wawancara dengan masyarakat dan obervasi penulis dapat simpulkan hasil seleksi yang dikerlurakan oleh Bapak Wali Nagari Sontang Cubadak dalam mengeluarkan tidak sesuai dengan jadwal ataupun peraturan yang ada, sehingga membuat masyarakat bertanya-tanya lama tentang hasil seleksi pengangkatan perangkat Nagari ini.

\section{Akses Informasi}

Adanya mekanisme tentang penyempaian informasi yang akurat, memungkinkan masyarakat dapay memperoleh informasi yang jelas dan transparan. 


\section{a. Pengumuman}

Didalam pengangkatan perangkat Nagari Tim melakukan penjaringan kepada masyarakat tentang adanya jabatan kosong, dan mengenai mekanisme didalam proses maupun pengangkatan perangkat Nagari yang baru dimana dalam menyampaikan pengumuman ini juga sudah di jelaskan dalam Perda Nomor 11 tahun 2016 bahwasanya diadakannya pengumuman tentang jabatan perangkat Nagari yang kosong.

Berdasarkan wawancara yang dilakukan kepada Bapak Hendra selaku Wali Nagari Sontang cubadak sebagai berikut:

"Pengumuman mengenai pengangkatan perangkat Nagari melalui media memang tidak ada." ( wawancara, 15 maret 2018, kantor Wali Nagari Sontang Cubadak)

Selanjutnya, penulis juga melakukan wawancara kepada pihak masyarakat Nagari Sontang cubadak yaitu bapak Makmur sebagai berikut:

"Informasi melalui media sosial memang tidak ada, ya mungkin kan namanya di kampung masyakarat juga kurang mengakses ifnormsi dari media sosial". (wawancara, 17 maret 2018, 20.10 Wib, dirumah bapak Makmur).

Berdasarkan kesimpulan dari hasil wawancara Penulis dengan masyarakat dan observasi penulis dapat simpulkan bahwa pengangakatan perangkat Nagari sontang ini dalam menggunakan media sosial masih kurang.

b. Surat Edaran

Surat edaran merupakan surat yang isinya menyangkut informasi yang dibuat secara resmi didalam suatu lembaga atau instansi, atau organisasi atau suatu surat pemberitahuan secara resmi yang ditujukan untuk berbagai pihak yang terkait

Berdasarkan wawancara yang dilakukan kepada Bapak Hendra selaku Wali Nagari Sontang cubadak sebagai berikut:

"Mengenai surat edaran, kami memang sudah membuat surat edaran, kami tujukan ke tempat-tempat masyarakat yang ramai penduduk, dan kami juga sudah membuat selebaran untuk di sebarkan ke masyarakat, tapi kalau masyarakat sebagian tidak mengetahuinya ya mungkin setelah di sebarkan selebaran ini ada masyarakat yang membuangnya, ataupun tidak memberitahukan kepada pihak lain, mungkin dia tidak ingin banyak yang mendaftar, ya kamu tau sendiri lah masyarakat ini sifatnya berbedabeda." ( wawancara, 15 maret 2018, kantor Wali Nagari Sontang Cubadak).

Selanjutnya, penulis juga melakukan wawancara kepada pihak masyarakat Nagari Sontang Cubadak yaitu Bapak Makmur sebagai berikut:

"Surat edaran yang diedarkan oleh bapak Wali ataupun panitia tim seleksi belum diterima oleh semua kepala jorong ataupun lapisan masyarakat, dimana sebahagian masyarakat ini tau bahwa adanya pemilihan perangkat Nagari yang baru setelah di adakannya proses seleksi."(wawancara, 17 maret 2018, 20.20 Wib, dirumah bapak Makmur). 
Berdasarkan kesimpulan dari hasil wawancara Penulis dengan masyarakat dan obervasi penulis dapat simpulan bahwa proses akses informasi melalui surat edaran ini masih sangat kurang, karna dalam penyampaikan informasi mengenai dibukanya pendaftran perangkat Nagari yang baru masyarakat masih banyak yang belum mengetahuinya.

c. Kegiatan Sosialisasi

Kegiatan Sosialisasi merupakan serangkaian proses penanaman atau transfer kebiasaan atau nilai dalam sebuah kelompok atau masyarakat. Beberapa sosiolog menyebutkan bahwa sosialisasi dianggap sebagai teori mengenai peranandan fungsi (role theory). sebab dalam proses sosialisasi diajarkan peran-peran yang harus dijalankan oleh individu.

Berdasarkan kesimpulan dari wawancara yang dilakukan oleh Penulis dengan Bapak Hendra selaku Wali Nagari Sontang cubadak sebagai berikut:

"Kami dari pihak Wali Nagari sudah membuat sosialisasi dimana soasialisai ini kami mengundang seluruh kepala jorong, tetapi pada saat itu tidak semua kepala jorong yang dating. Kalau untuk sosialisasi dengan masyakat kami tidak melakukannya." (wawancara, 15 maret 2018, kantor Wali Nagari Sontang Cubadak).

Selanjutnya, penulis juga melakukan wawancara kepada pihak masyarakat Nagari Sontang cubadak yaitu bapak Makmur sebagai berikut:

"Saya saja selaku kepala jorong tidak diundang dalam rapat sosialisasi yang diadakan oleh Bapak Wali, dan juga masih ada kepala jorong yang tidak diundang dan sama sekali tidak tau bahawasanya bapak wali mengadakan sosialisasi tentang pengangkatan perangkat Nagari". (wawancara, 17 maret 2018, 20.20 Wib, dirumah Bapak Makmur).

Berdasarkan wawancara yangpenulis lakukan dengan pihak masyarakat dan obervasi penulis dapat simpulan bahwa proses akses informasi melalui sosialisasi masih kurang optimal karna masih banyak juga masrakat yang tidak tau tentang diadakannya seleksi perangakat Nagari yang baru meskioun sudah diadakannya sosialisasi.

\section{Pengawasan}

Peraturan yang mengatur kewajiban pemerintah daerah menyediakan informasi kepada masyarakat, serta menumbuhkan budaya di tengah masyarakat untuk mengkritisi kebijakan yang dihasilkan pemerintah daerah.

a. Pengawasan pemerintah

Pengawasan pemerintah adalah pengawasanyang dilakukan oleh orang atau badan yang ada di dalam lingkungan unit organisasi yang bersangkutan atau pengawasanyang dilakukan secara rutin oleh inspektorat jenderal pada setiap kementerian dan inspektorat wilayah untuk setiap daerah yang ada di Indonesia, dengan menempatkannya di bawah pengawasan Kementerian Dalam Negeri.

Berdasarkan wawancara yang dilakukan kepada Bapak Aswar, SH selaku Camat Kecamatan Padang Gelugur.

"Pengawasan yang kami lakukan sudah sangat baik, dari soal ujian tertulis yang masih disegel sampai saat ujian dilakukan, dari hasil seleksi yang benar dimana sudah djumlahkan dengan ujian wawancara juga, dan 
panitia tim seleksi juga sudah memberikan hasilnya kepada bapak wali Nagari, dan kami benar-benar menyaksikan ataupun mamantau proses seleksi ini." (Wawancara, 14 maret 2018, jam 10.00 Wib dikantor Camat Padang Gelugur)

Hal senada juga di ungkapkan oleh Ibuk S. Sirait Selaku pengawas panitia tim seleksi sebagi berikut:

"Pengawasan yang kami lakukan dengan Bapak Camat saya rasa sudah sangat ketat sekali, dan kami benar-benar mengikuti semua proses yang dilakukan, dari pertama pembentukan paniti tim seleksi, dibukanya pendataran untuk calon perangkat Nagari yang baru, proses seleksi, sampai pengeluaran hasil seleksi". (wawancara, 14 maret 2018, jam 13.30 wib).

Berdasarkan hasil wawancarayang penulis lakukan dapat diambil kesimpulan bahwa pengawasanyang dilakukan sudah sangat baik, dimana pengawasan dilakukan dari awal pelaksanaan proses seleksi sampai kepada hasil seleksi.

b. PengawasanMasyarakat

Partisipasi rakyat amat penting, sebab tanpa keterlibatan rakyat maka kebijakan penguasa akan sangat jauh dari aspirasi, kepentingan, dan kebutuhan rakyat. Di samping itu, tiadanya partisipasi rakyat juga mengakibatkan kendornya pengawasanmasyarakat (social control), sehingga banyak terjadi pengingkaran terhadap amanat rakyat dan munculnya berbagai penyalahgunaan kekuasaan.

Berdasarkan wawancara yang dilakukan kepada pihak masyarakatNagari Sontang Cubadak yaitu Bapak Indra sebagai berikut:

"Pengawasan yang dilkukan masyarakat ya sampai sebatas apa, kami dari pihak masyarakat hanya melihat dan bagaimana proses nya, dan kami merasa pihak pemerintah masih kurang dalam menyampaikan seluruh informasi kepada semua masyarakat, dimana itu akan menjadi tanda tanya semua masyarakat". (wawancara, 18 maret 2018, 19.45 Wib, dirumah Bapak indra).

Hal senada juga disampaikan oleh Bapak Makmur sebagai berikut:

"Pengawasan dari pihak masyarakat sudah sangat berperan sekali dimana masyarakat benar-benar ikut memantau jalannya proses seleksi dimana masyarakat merasa dari pihak Wali Nagari dan Tim Panitia seleksi masih kurang jelas dalam menyampaikan informasi dan setengah-setengah dalam menyampaikan informasi, sehingga terjadi demo ratusan masyarakat Sontang Cubadak ke kantor Camat untuk memepertanyakan kembali hasil seleksi perangkat Nagari yang baru ini".(wawancara, 17 Maret 2017, 20.20 Wib dirumah Bapak Makmur).

Berdasarkan wawancara yang penulis lakukan dengan pihak masyarakat dan observasi penulis dapat simpulkan bahwa pengawasanyang dilakukan oleh masyarakat sangat kurang. karna masyarakat lebih memilih tidak mau tau akan berjalannya proses pemilihan perangkat Nagari sesuai atau tidak dengan aturan. 


\section{Hambatan Pelaksanaan Azaz Transparansi}

Hambatan atau kendala ialah penghalang terlaksananya sebuah kebijakan yang telah ditetapkan, hal ini dapat terjadi karena beberapa faktor. Adapun hasil wawancara seputar pertanyaan tentang hambatan ialah "Faktor Penghambat Pelaksanaan Asas Transparansi Dalam Proses Pengangkatan Perangkat Nagari

Berdasarkan wawancara dengan Bapak Hendra selaku Wali Nagari Sontang Cubadak sabagai berikut:

"Hambatan di dalam pelaksanaan pengangkatan perangkat Nagari ini saya rasa tidak ada, dan semua berjalan mulus, tapikan namanya masyarakat, pasti ada yang tidak suka, ada yang suka, dan juga kemarin pada saat penyampaian informasi pembukaan pendaftaran itu sudah disampaikan ke masyarakat, tapikan sebehagian masyarakat tidak ingin kalau masyarakat lain tau ada penerimaan perangkat Nagari yang baru, makanya informasi atau selebaran itu di buang, sehingga hal tersebut membuat konflik, sampai-sampai setelah selesi proses seleksi pengangkatan perangkat Nagari masyakat demo terhadap hal tersebut.". (Wawancara, 15 Maret 2018, jam 09.30 Wib, kantor Wali Nagari Sontang Cubadak).

Berdasarkan wawancara dengan Bapak Aswar, SH sebagai Camat Padang Gelugur sabagai berikut:

"Hambatan di dalam pelaksanan ini sebenarnya kurangnya komunikasi antara pejabat Kantor Wali Nagari Sontang Cubadak itu sendiri dengan masyarakatnya. Dimana Wali Nagari dalam menyampaikan informasi tidak benar-benar memastikan kalau informasi tersebut sudah sampai kepada masyarakat, dan itulah yang membuat masyarakat tidak suka dengan kebijakan tersebut, sehingga terjadilah permasalahan sekarang sampai adanya demo yang dilakukan masyarakat sontang cubadak, dan menyebabkan gagalnya pelantikan perangkat Nagari yang baru."(Wawancara, 14 maret 2018, jam 10.00 Wib dikantor Camat Padang Gelugur).

Penulis juga melakukan wawancara dengan Bapak Makmur selaku masyarakat sontang cubadak sebagai berikut:

"Hambatan sehingga terjadi seperti sekarang ini ya karna bapak wali pilih kasih terhadap masyarakat, mana yang dekat dengan beliau itu di dahulukannya, jadi banyak masyarakat marah terhadap sikap beliau. Masalah ini sampai kepada pihak kabupaten, dan pihak inspektorat juga sudah datang ke kantor Wali Nagari untuk melakukan pemeriksaan". (wawancara dengan Bapak Makmur, jam 20.20 Wib di rumah bapak Makmur).

Berdasarkan wawancara diatas peneliti melakukan analisis bahwa hambatan yang di hadapi oleh Pelaksanaan Asas Transparansi Dalam Proses Pengangkatan Perangkat Nagari (Studi Kasus Nagari Sontang Cubadak Kecamatan Padang Gelugur Kabupaten Pasaman Provinsi Sumatera Barat)terletak padawali Nagarinya. Dimana wali Nagari kurang peduli dan pekaterhadap keinginan dan tuntutan masayarakat, mereka menganggap masyarakatakan menerima begitu saja apa keputusan mereka sehingga perintah dari kecamatan sering tak dilaksanakan sebagimana camat memerintahkan. 


\section{SIMPULAN DAN SARAN \\ Simpulan}

Berdasarkan hasil analisa dan temuan serta pembahasan pada bab-bab sebelumnya maka pada bab ini peneliti akan membuat suatu kesimpulan sert amemberikan saran-saran yang diharapkan bisa mampu mendatangkan manfaat bagi Kantor Wali Nagari Sontang Cubadak agar Pelaksanaan Asas Transparansi Dalam Proses Pengangkatan Perangkat Nagari Sontang Cubadak dapat berjalan sebagaimana mestinya dan sesuai dengan Peraturan Daerah Nomor 11 tahun 2016 Tentang Pengangkatan dan Pemberhentian Perangkat Nagari.

Adapun hasil dari penelitian ini yang dapat peneliti sajikan antara lain sebagaiberikut:

1. Pelaksanaan Asas Transparansi Dalam Proses Pengangkatan Perangkat Nagari (Studi Kasus Nagari Sontang Cubadak Kecamatan Padang Gelugur Kabupaten Pasaman Provinsi Sumatera Barat) kurang berjalan maksimal hal ini dikarenakan kurang optimalnya Wali Nagari dan Panitia Tim seleksi di dalam penggunaan Peraturan Daerah Nomor 11 Tahun 2016 Tentang Pengangkatan Dan Pemberhentian PerangkaT Nagari sehingga menciptakan kurangnya transparansi dari pihak wali Nagari, terlihat dari rekrutmen yang kurang terbuka, dan akses informasi yang tidak terjangkau oleh seluruh masyarakat sebagaimana yang telah diatur dalam Peraturan Daerah Nomor 11 Tahun 2016.

2. Hambatan yang pada Pelaksanaan Asas Transparansi Dalam Proses Pengangkatan Perangkat Nagari adalah kurang baiknya pengawasan dengan pihak kecamatan dan kurang baiknya komunikasi antara pemerintahan Nagari dengan masyarakat Sontang Cubadak.

\section{Saran}

Adapun saran penulis mengenai Pelaksanaan Asas Transparansi Dalam Proses Pengangkatan Perangkat Nagari (Studi Kasus Nagari Sontang Cubadak Kecamatan Padang Gelugur Kabupaten Padaman Provinsi Sumatera Barat) adalah:

1. Perlu adanya upaya membangun komunikasi yang baik antara pejabat dengan masyarakat sehingga terjadinta kominikasi yang baik.

2. Perlu adanya pengawasan yang lebih baik lagi sehinggamasyarakat benarbenarmengetahui informsi yang ada dari pihak pemerintah.

3. Mensosialisasikan kepada seluruh masyarakat bahwa adanya pemilihan perangkat Nagari yang baru dan undang-undang yang mengatur tentang pengangkatan perangkat Nagari.

4. Perlunya pengawasan antara pihak Wali Nagari dengan pemerintah kecamatan.

\section{DAFTAR PUSTAKA}

Adrianto,Nico.2007. Transparansi dan Akuntabilitas melalui e-Goverment. Bayu Media, Malang.

Badriyah, R.S., 2017. Pengaruh Rekruitmen Perangkat Desa Terhadap Kinerja Perangkat Desa di Desa Andapraja Kecamatan Rajadesa Kabupaten Ciamis. Jurnal Ilmiah Administrasi Publik Dinamika, Vol.4, No.3.

Politik, Universitas Galuh (Unigal), Ciamis, Jawa Barat. 
Dwiyanto, Agus. 2006. Mewujudkan Good Governance Melayani Publik. Gadjah Mada University, Yokyakarta.

Faturahman, B. M. (2018). Aktualisasi Nilai Demokrasi dalam Perekrutan dan Penjaringan Perangkat Desa. Sospol: Jurnal Sosial Politik, 4(1), 132-148.

Kushandajani. 2016. Implikasi UU No. 6Tahun 2014 tentang Desa terhadapPenyelenggaraan Pemerintahan Desa. Jurnal IImiah IImu Pemerintahan, Volume 2,No. 1.

Meigelheis, Y. 2018. „Pelaksanaan Rekrutmen Perangkat Desa di Kabupaten Kulon Progo". Skripsi. Yogyakarta: Program Studi Ilmu Pemerintahan APMD.

Nur'aini Muslim, dan Irwan Nasution, "Kinerja Aparat Desa dalam Penyelenggaraan Pemerintahan di desa Pantai Labu Pekan", Jurnal IImu Pemerintahan dan Sosial Politik.UMA, 2 (2) (2014), h. 100.

Perda Kabupaten Pasaman Nomor 11 tahun 2016.

Peraturan Menteri Dalam Negeri No 83 tahun 2015 tentang pengangkatan dan Pemberhentian Perangkat Desa.

Romli, Ombi., \& Nurlia, Elly. (2017). Lemahnya Badan Permusyawaratan Desa (BPD) Dalam Melaksanakan Fungsi Pemerintahan Desa (Studi Desa Tegalwangi Kecamatan Menes Kabupaten Pandeglang). Cosmogov; Jurnal IImu Pemerintahan, Vol.3, (No.1), p.36.

Sedarmayanti, 2009. Reformasi Administarsi Publik, Reformasi Birokrasi, dan Kepemimpinan Masa Depan (Mewujudkan Pelayanan Prima Dan Kepemerintahan Yang Baik). Refika Aditama, Bandung.

Sugiono, 2011. Metode Penelitian Administrasi. Alfabeta, Bandung.

Suharto, G, D. 2016. Membangun Kemandirian Desa. Pustaka Pelajar. Yogyakarta.

Surat Edaran Bupati Kabupaten Pasaman Nomor 140/4197/PemNag-2017.

Somad, Kemas A. (2012). Reformasi Birokrasi Desa Menuju Pemerintahan desa yang Demokratis. Jurnal Masalah-Masalah Hukum, Jilid 41, (No.4), p.487.

Undang- Undang Nomor 23 tahun 2014 tentang Pemerintah Daerah.

Undang-Undang N0. 6 Tahun 2014 Tantang Desa.

Utami, N., A. (2015). Pengaruh Rekruitmen Perangkat Desa Terhadap Kinerja Perangkat Pemerintah Desa di Kecamatan Randudongkal Kabupaten Pemalang. Skripsi. Fakultas IImu Sosial Dan IImu Politik. Universitas Pancasakti Tegal. 